UDC 622.1:528

T. K. Issabek, Dr. Sc. (Tech.), Prof., orcid.org/0000-0001-7718-933X,

V. F. Dyomin, Dr. Sc. (Tech.), Prof., orcid.org/0000-0002-1718-856X, D. T. Ivadilinova, orcid.org/0000-0002-9731-0587
DOI: $10.29202 /$ nvngu/2019-2/2

Karaganda State Technical University, Karaganda, the Republic of Kazakhstan, e-mail: dinulb@mail.ru

\title{
METHODS FOR MONITORING THE EARTH SURFACE DISPLACEMENT AT POINTS OF SMALL GEODETIC NETWORK UNDER THE UNDERGROUND METHOD OF COAL DEVELOPMENT
}

Purpose. Developing an efficient and high accuracy methodology of observing the earth surface deformations when mining minerals by the underground method.

Methods. Experimental grapho-analytical methods as well as mathematical modeling were applied.

Findings. There is presented a methodology and results of processing the data of observations of the earth surface displacements when mining coal at Kostenko mine of the Coal Department of ArcelorMittal Temirtau JSC, Karaganda Coal Basin. The displacement measurements were performed at points of the small geodetic network using the GNSS technologies with accuracy acceptable for the satellite geodetic network of class 1.

The results confirm the GNSS methods effectiveness in studying the earth surface displacements in coal mine conditions. Displacement vectors of the GNSS points were determined; numerical values of the relative vertical and horizontal displacements of the points were obtained.

Originality. A new technique for making geodesic measurements was developed when studying the earth surface displacements during its underworking by means of building local small geodynamic networks. For the first time the observations of the earth surface displacements due to its undermining in the territory of the Karaganda coal basin were carried out not along the profile lines but as a result of a detailed surface survey.

Practical value. The proposed method for performing geodetic measurements using the GNSS technology to study the earth displacements has made it possible to determine the parameters of the displacement process with a high degree of accuracy and can serve as the basis for organizing geodetic monitoring at all the mines of the Karaganda coal basin. The main tool for monitoring man-made processes was a network of specially designed benchmarks in the field. With systematic monitoring, when initially there are implemented the measures to form a geodynamic polygon, the greatest degree of prediction of the risks of field exploitation is achieved.

Keywords: coal, supervision, earth movement, GNSS, accuracy of measurements, detailed survey, underground mining

Introduction. At the moment, with the advent of new methods and technologies for monitoring the earth surface displacements, the issues of undermining structures and natural objects in coal-bearing areas are being improved in terms of a variety of factors, such as improving the accuracy of the results, reducing the time of observation and reducing the financial cost of the work.

Studying the issues related to the development of methods for observing deformations of the earth surface in the areas mined by underground coal mines in the territory of the former USSR was carried out by scientists from the All-Russian Scientific-Research Institute of Nuclear Physics (Samarin V.P., Mayevsky F.M., Soshenko A.I., Muller R.A., Akimov A.G., Zapadinsky L.A., Shagalov S.E., Biryukov V.V., Sinopalnikov S.G., Reshetov G.A. and others), from the Ukrainian branch of the All-Russia Scientific-Research Institute (Markov V.V., Spiridonov N.A., Matyushenko M. D., Vyrvo V. M., Vyaznikovtsev O. I., Molkov V. S. and others), as is evidenced by many publications on this subject.

In Kazakhstan in the conditions of the Karaganda coal basin, the problem was studied by the employees of the Kazakh branch of the All-Russia Institute of Scien-

(C) Issabek T. K., Dyomin V. F., Ivadilinova D. T., 2019 tific Research and Development (Kleschev P.E., Poklad G. G., Gadymba I. M., Vedyashkin A. S., Elimanov K. K., Pozhemyatkas N.I., Blischenko V.N., Belyavtseva V.V., Lee R. V., Zhukenova M.N., and others), as well as scientists from KazNRTU N. A. Satpayev.

Presentation of the main research. Coal mining operations under built-up areas include a set of mining activities to increase the volume of extracted minerals from the subsoil, to assess the impact of various processes occurring in the thickness of rocks and on the earth surface, predicting and reducing possible significant chemical and hydrological transformations, releasing toxic gases and groundwater to the earth surface. The permissible level of impact of underground mining operations on the objects located on the surface is determined by their purpose, type of construction, maximum permissible deformations, location, and social conditions.

It is known that the practice of developing minerals has shown the increasing load on rock massifs located above the layers under development, which leads to redistribution of the stress-strain state of the massif and to undesirable consequences and irreversible processes in the environment.

For example, within the displacement trough, there occurred the earth surface deformations (Fig. 1), which clearly shows the extent of the damage. 


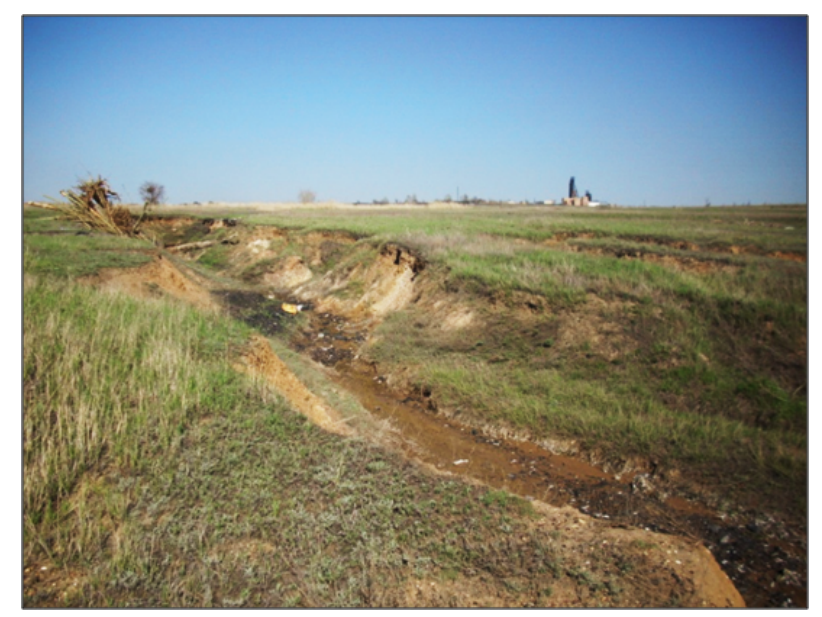

Fig. 1. The earth surface deformations in the territory of Kostenko mine

Therefore, systematic instrumental observations and prediction of the stress-strain state of the rock massif can reduce damage, and sometimes even help to avoid negative consequences.

The main tool for monitoring man-made processes is a network of specially designed observational benchmarks in the field. With systematic monitoring, when initially there are taken measures to form a geodynamic polygon, the greatest degree of prediction of the risks of field exploitation is achieved.

The main purpose of observations is determining the quantitative and qualitative values of deformations to assess the degree of stability of the structure for implementing timely measures that will ensure its normal operation. In addition, the results of observations allow checking the correctness of the design calculations, identifying regularities of predicting the process of displacement.

To control the undermined earth surface displacements during underground coal mining, it is recommended, according to [1], to design observation stations in the form of core lines located along the strike, and to carry out linear and height measurements using traditional geodetic and surveying methods [2]. However, the performing geodetic observations at the points of core lines does not fully take into account the entire process of surface displacement, and the measured displacements determine the ones only relative to a specific core line and are not oriented in space, at this, the obtained data are statistical in nature.

For this purpose there is proposed a method of the GNSS measurements at points of a small geodetic network [3] that allows measuring the data in scale; obtaining dynamic data that reflects the displacement process in real time; determining the magnitude of displacements oriented spatially; ensuring high accuracy of measurements without significant costs in comparison with traditional geodetic methods [4].

This method was used to study the process of the earth displacements in the territory of Kostenko mine of the Coal Department of ArcelorMittal Temirtau JSC (Karaganda Coal Basin) in the course of underground mining. The task of the study was to determine the earth surface displacements [5], as well as their accuracy using the GNSS measurements at the points of the designed small geodetic network.

For the study there was selected a period from 2008 to 2010 , when sections of highways, railway sections, high-voltage transmission lines, points of the State geodetic network were simultaneously included in the zone of influence of mining operations on the surface.

In this period there was developed longwall $45 \mathrm{~K}_{2}$ $\mathrm{K}_{3}-3,44 \mathrm{~K}_{7}-3,48 \mathrm{~K}_{12}-1$-в. The sediment thickness in the territory under consideration was $70 \mathrm{~m}$. The enclosing rocks were composed of sandstones, mudstones, and aleurolites [6]. Mining conditions [7] of the coal reserves being processed are given in Table 1 .

As a result of the reconnaissance of the territory of the land allotment of Kostenko mine, it was established that from the points of the State geodetic network the polygonometry points of the $4^{\text {th }}$ class were preserved: PP No.0351, 0562 and 0383 in the territory of the administrative-domestic complex; PP No. 1433 and 9389 on the wasteland along the road; PP No.9863 and the triangulation point of class 2 on the building of the centrally-related cage shaft (CRCS).

These points did not provide complete control of the displacement process therefore, additional points $\mathrm{Rp} 1$, Rp2, Rp3, Rp4 (Fig. 2) [8] were introduced along the strike and across the longwalls.

For obtaining reliable results, there was performed a preliminary calculation of the network accuracy in the static mode using the GNSS receiver Leica GX1220

$$
\begin{gathered}
m_{\text {plan }}=3 \mathrm{~mm}+0.5 \mathrm{~mm} / \mathrm{km}=3+0.5 \cdot 3=4.5 ; \\
m_{\text {height }}=6 \mathrm{~mm}+0.5 \mathrm{~mm} / \mathrm{km}=6+0.5 \cdot 3=7.5 ; \\
m_{a}=\sqrt{m_{\text {plan }}^{2}+m_{\text {height }}^{2}}=8.74,
\end{gathered}
$$

\section{Table 1}

Mining-technical conditions of the coal reserves developed

\begin{tabular}{|l|c|c|c|}
\hline Indicator name & $\begin{array}{c}\text { Longwall 45 } \\
\mathrm{K}_{2}-\mathrm{K}_{3}-3\end{array}$ & $\begin{array}{c}\text { Longwall 44 } \\
\mathrm{K}_{7}-3\end{array}$ & $\begin{array}{c}\text { Longwall 48 } \\
\mathrm{K}_{12}-1-\mathrm{B}\end{array}$ \\
\hline $\begin{array}{l}\text { Average depth of } \\
\text { development, } \mathrm{m}\end{array}$ & 620 & 480 & 310 \\
\hline $\begin{array}{l}\text { Retrievable } \\
\text { reservoir } \\
\text { capacity, } \mathrm{m}\end{array}$ & 5.6 & 1.9 & 2.7 \\
\hline Dip angle, deg. & 9 & 7 & 6 \\
\hline Length, m & 1100 & 1350 & 840 \\
\hline Start of mining & $\begin{array}{c}\text { February } \\
2008\end{array}$ & $\begin{array}{c}\text { November } \\
2009\end{array}$ & $\begin{array}{c}\text { March } \\
2008\end{array}$ \\
\hline $\begin{array}{l}\text { End of mining } \\
\text { October }\end{array}$ & $\begin{array}{l}\text { June } \\
2010\end{array}$ & $\begin{array}{c}\text { January } \\
2009\end{array}$ \\
\hline $\begin{array}{l}\text { The speed of the } \\
\text { face advancing, } \\
\text { m/month [9] }\end{array}$ & 62 & 192 & 81 \\
\hline $\begin{array}{l}\text { Method of the } \\
\text { roof control [10] }\end{array}$ & $\begin{array}{c}\text { Full } \\
\text { collapse }\end{array}$ & $\begin{array}{c}\text { Full } \\
\text { collapse }\end{array}$ & $\begin{array}{c}\text { Full } \\
\text { collapse }\end{array}$ \\
\hline
\end{tabular}




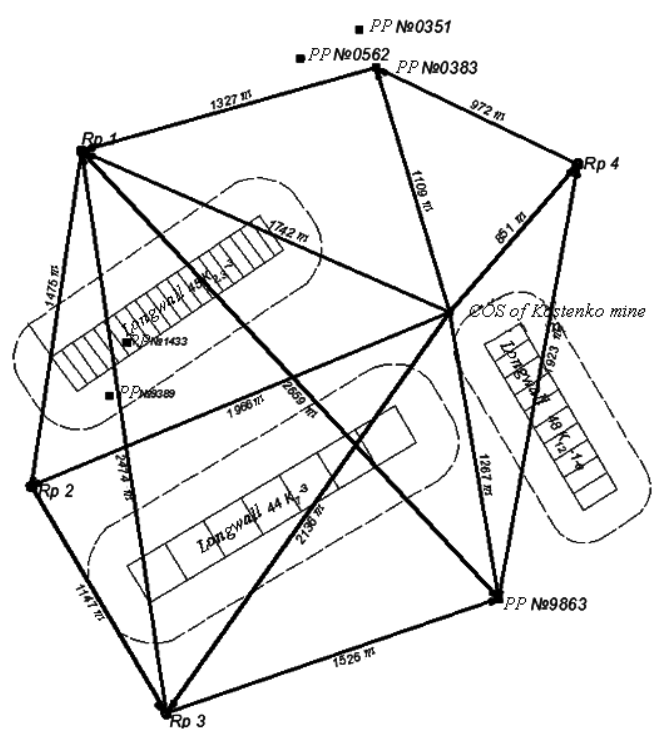

Fig. 2. The geodetic network project

where $m_{\text {plan }}$ is the measurement error in plan, mm; $m_{\text {height }}$ is the measurement error in height, $\mathrm{mm} ; m_{a}$ is the absolute error, $\mathrm{mm}$.

The limiting relative error of the route was determined by the formula [11]

$$
\begin{gathered}
m_{a} / a=8.74 / 2659000 \\
m_{a} / a=1 / 304233
\end{gathered}
$$

where $m_{a}$ is the absolute error of the route weak side, $\mathrm{mm} ; a$ is the length of the route weak side, $\mathrm{mm}$.

The obtained value of the limiting relative error of the route 1/304 233 is smaller than the allowable one for the satellite city geodetic network of class (SGCN-1) $1 / 150000$ [12], thus, the network designed corresponds to the instruction requirements.

The number of lines in the route is 11 (Table 2).

The basic lines of the network are between the points of the COS and Rp2, the COS and Rp4. In addition to observations using a GNSS receiver, there were also carried out control measurements of the length of lines using a tacheometer.

The long side of the route between the laid-out point Rp1 and the existing point PP No. 9863 was 2659 m, the

Table 2

Dimensions of the satellite GNSS network sides

\begin{tabular}{|l|c|c|c|c|c|c|}
\hline $\begin{array}{c}\text { From point } \\
\text { to point }\end{array}$ & $\begin{array}{c}\text { PP No } \\
0383\end{array}$ & $\begin{array}{c}\text { PP No } \\
9863\end{array}$ & Rp1 & Rp2 & Rp3 & Rp4 \\
\hline COS & 1109 & 1267 & 1742 & 1966 & 2136 & 851 \\
\hline PP No.0383 & - & - & 1327 & - & - & - \\
\hline Rp1 & - & 2659 & - & 1475 & - & - \\
\hline Rp2 & - & - & - & - & 1147 & - \\
\hline Rp3 & - & 1526 & 2474 & - & - & - \\
\hline PP No.9863 & - & - & - & - & - & 1923 \\
\hline Rp4 & 972 & - & - & - & - & - \\
\hline
\end{tabular}

short side between COS and Rp4 was $851 \mathrm{~m}$, the average length of the sides was $1612.43 \mathrm{~m}$. For GNSS measurements at the points of the satellite network there was used the GNSS receiver Leica GX1220.

Evaluation of the accuracy of determining the plan and altitude position of the observed points is given in Table 3.

Controlling the line length changes was performed using a Leica TPS407 electronic tacheometer. The results are shown in Table 4.

The results of measurements on the GNSS network points (Fig. 2) using the Leica GX1220 GNSS receiver, are shown in Table 5. According to the measurement data at the points of the small geodetic network, the displacement vectors of the network points were determined (Fig. 3) and the following was established:

1. The accuracy of determining the plan coordinates was $4 \mathrm{~mm}$, height $7 \mathrm{~mm}$.

2. The maximum displacement at the GNSS point located on the COS building was $8 \mathrm{~mm}$, which allowed using this point as the basic station.

3. At the GNSS points of the Rp2 and Rp3 networks, the values are obtained indicating that there are significant displacements of the earth surface in the mine field (about $1 \mathrm{~m}$ ) relative to the initial point of the network. The displacement vectors of the points were obtained with the accuracy of $8 \mathrm{~mm}$.

4. At point PP No. 0383 subsidence of the earth surface is less significant (the maximum value is $6.2 \mathrm{~cm}$ ). This is due to the fact that the point is installed above the safety pillar entirely [13] that is located under the building of the administrative and living complex of the mine.

The analysis of satellite observations made indicates that at polygonometry points No. 9389, No. 1433, at the laid down points Rp1, Rp2, Rp3, Rp4, displacements of the earth surface reach significant values, which is due to

Table 3

Evaluation of the accuracy of determining the plan and height position of the observed points of the

\begin{tabular}{|c|c|c|c|c|c|c|c|}
\hline 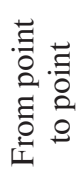 & Error & $\begin{array}{l}\infty \\
\infty \\
\tilde{o} \\
0 \\
\dot{z} \\
\hat{a} \\
\tilde{a}\end{array}$ & $\begin{array}{l}\hat{0} \\
\& \\
o \\
o \\
z \\
a\end{array}$ & Rp1 & Rp2 & Rp3 & Rp4 \\
\hline \multirow[t]{2}{*}{ COS } & In plan & 3.55 & 3.63 & 3.87 & 3.98 & 4.07 & 3.43 \\
\hline & In height & 6.55 & 6.63 & 6.87 & 6.98 & 7.07 & 6.43 \\
\hline
\end{tabular}
satellite GNSS network, mm

Table 4

Dimensions of the basic lines lengths of the satellite GNSS network, $\mathrm{m}$

\begin{tabular}{|c|c|c|c|c|}
\hline Basic line & $\begin{array}{c}\text { October } \\
2008\end{array}$ & $\begin{array}{c}\text { March } \\
2009\end{array}$ & $\begin{array}{c}\text { September } \\
2009\end{array}$ & $\begin{array}{c}\text { March } \\
2010\end{array}$ \\
\hline COS-Rp2 & 1966.11 & 1965.90 & 1965.44 & 1964.79 \\
\hline COS-Rp4 & 851.02 & 850.92 & 850.83 & 850.72 \\
\hline
\end{tabular}


Table 5

Displacements of the GNSS network points, $m$

\begin{tabular}{|c|c|c|c|}
\hline \multirow{2}{*}{ Observation point } & \multicolumn{3}{|c|}{ March 2009} \\
\hline & $\mathrm{X} 2-\mathrm{X} 1$ & $\mathrm{Y} 2-\mathrm{Y} 1$ & $\mathrm{Z} 2-\mathrm{Z} 1$ \\
\hline $\mathrm{COS}$ & 0.008 & -0.007 & -0.008 \\
\hline PP No.0383 & -0.020 & -0.022 & -0.01 \\
\hline PP No.863 & 0.034 & 0.029 & -0.11 \\
\hline Rp1 & -0.050 & 0.411 & -0.17 \\
\hline Rp2 & 0.083 & 0.052 & -0.31 \\
\hline Rp3 & 0.001 & 0.003 & -0.03 \\
\hline Rp4 & -0.064 & -0.044 & -0.02 \\
\hline \multirow[t]{2}{*}{ Observation point } & \multicolumn{3}{|c|}{ September 2009} \\
\hline & $\mathrm{X} 3-\mathrm{X} 2$ & $\mathrm{Y} 3-\mathrm{Y} 2$ & $\mathrm{Z} 3-\mathrm{Z} 2$ \\
\hline $\mathrm{COS}$ & 0.004 & -0.005 & 0.000 \\
\hline PP No.0383 & -0.029 & -0.009 & -0.020 \\
\hline PP No.863 & 0.027 & 0.020 & -0.080 \\
\hline Rp1 & -0.139 & 0.064 & -0.350 \\
\hline Rp2 & 0.306 & 0.340 & -0.230 \\
\hline Rp3 & 0.000 & 0.001 & -0.050 \\
\hline $\mathrm{Rp} 4$ & -0.092 & -0.008 & -0.150 \\
\hline \multirow[t]{2}{*}{ Observation point } & \multicolumn{3}{|c|}{ March 2010} \\
\hline & $\mathrm{X} 4-\mathrm{X} 3$ & $\mathrm{Y} 4-\mathrm{Y} 3$ & $\mathrm{Z} 4-\mathrm{Z3}$ \\
\hline $\mathrm{COS}$ & -0.003 & -0.004 & -0.010 \\
\hline PP No.0383 & -0.016 & -0.031 & -0.020 \\
\hline PP No.863 & 0.056 & 0.097 & -0.100 \\
\hline $\mathrm{Rp} 1$ & -0.055 & -0.040 & -0.410 \\
\hline Rp2 & 0.544 & 0.369 & -0.330 \\
\hline Rp3 & 0.488 & 0.839 & -0.320 \\
\hline Rp4 & -0.084 & -0.077 & -0.510 \\
\hline \multirow[t]{2}{*}{ Observation point } & \multicolumn{3}{|c|}{ October 2009-March 2010} \\
\hline & $\mathrm{X} 4-\mathrm{X} 1$ & $\mathrm{Y} 4-\mathrm{Y} 1$ & $\mathrm{Z} 4-\mathrm{Z1}$ \\
\hline $\mathrm{COS}$ & 0.009 & -0.016 & -0.02 \\
\hline PP No.0383 & -0.065 & -0.062 & -0.05 \\
\hline PP No.863 & 0.117 & 0.146 & -0.29 \\
\hline $\mathrm{Rp} 1$ & -0.244 & 0.435 & -0.93 \\
\hline $\mathrm{Rp} 2$ & 0.933 & 0.761 & -0.87 \\
\hline Rp3 & 0.489 & 0.843 & -0.40 \\
\hline $\mathrm{Rp} 4$ & -0.240 & -0.129 & -0.68 \\
\hline
\end{tabular}

the excavation of coal under them. And at polygonometry points No. 0351 , No. 0562 , No. 0383 , No. 9863 , and the point of triangulation at the COS displacements are within the measurement accuracy, this is because they are located within the boundaries of the administrative-domestic complex of Kostenko mine and the cage shaft, which are located on the safety pillar.

To estimate the displacement trough [14], a detailed GNSS survey of characteristic terrain points was made [15]. The number of such points was 141.

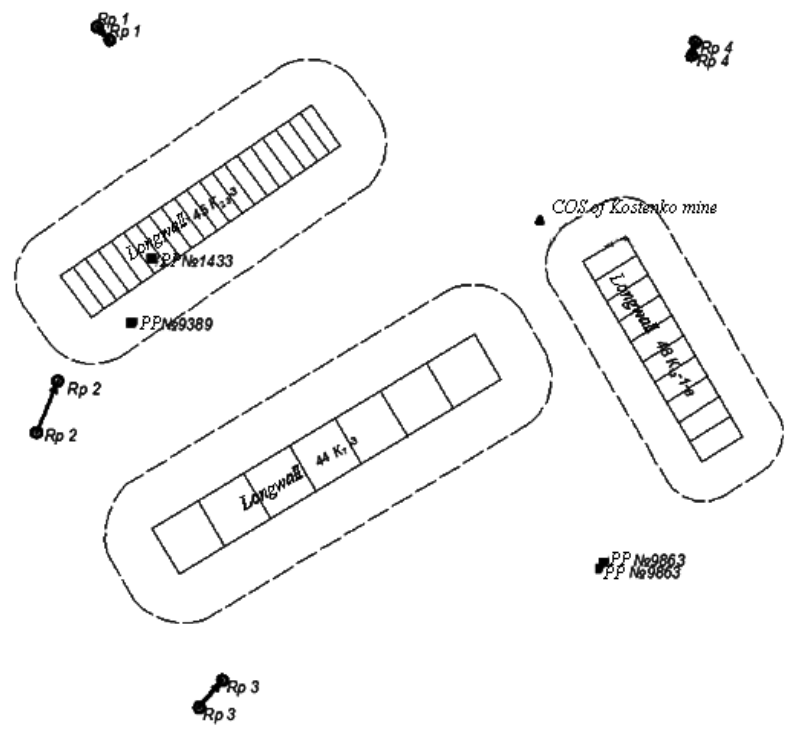

Fig. 3. Vectors of displacements of the satellite GNSS network points

The measurements were carried out in October 2009 and March 2010 using a fast static method, in which observations by a mobile station at a point were performed at one time.

The values of the maximum vertical displacements were obtained as a result of a detailed survey of the earth surface at point $80(101 \mathrm{~cm})$ located between longwalls $44 \mathrm{~K}_{7-3}$ and $48 \mathrm{~K}_{12}-1$-в. The horizontal displacement with the maximum value of $93.3 \mathrm{~cm}$ was fixed at point Rp2 of the small geodetic GNSS network.

The obtained values allow concluding that displacements are mainly directed across and along the strike of longwalls and that the initially selected basic lines of the projected dynamic GPS network have been correctly identified.

In order to determine the speed of the earth surface displacements above longwall $45 \mathrm{~K}_{2}-\mathrm{K}_{3}-3$, the elevations of points were measured additionally using a Leica TPS407 tacheometer. Earlier, in 1998-2006, 19931994, 1987-1989 in the area there were extracted reserves from longwall coal seams $\mathrm{K}_{3}, \mathrm{~K}_{2}, \mathrm{~K}_{1}$ [16]. Starting longwall $45 \mathrm{~K}_{2}-\mathrm{K}_{3}-3$ was made in February 2008.

For this longwall, the process of the earth surface displacement began at a certain distance from the mounting chamber, which can be determined by the formula [17]

$$
0.2 \times H=0.2 \times 620=120,
$$

where $H$ is the average depth of the longwall development, $\mathrm{m}$.

It was established that $120 \mathrm{~m}$ of longwall was worked out after 2 months after starting the longwall mining.

The maximum subsidence rate, $\mathrm{mm} / \mathrm{month}$ within the period of dangerous deformations, when the harmful effects of underground mining on structures and natural objects are manifested, for the Karaganda basin can be calculated by the formula [17]

$$
\mathrm{v}_{\text {theor }}=12 \frac{\mathrm{m} \cdot \mathrm{c} \cdot \cos \alpha}{H}\left(1+0.3 \frac{H_{1}}{H}\right) \text {, }
$$

ISSN 2071-2227, Naukovyi Visnyk NHU, 2019, № 2 
where $m$ is the developed seam thickness, $m ; \alpha$ is the seam dip angle, rad; $c$ is the rate of the breakage face advancement, $\mathrm{m} / \mathrm{day} ; H_{1}$ is the earlier undermined thickness, $\mathrm{m}$.

The maximum theoretical value of the subsidence rate for the 45 west longwall on the $K_{2}-K_{3}$ seam made, $\mathrm{mm} / \mathrm{month}$ [16]

$$
v_{\text {theor }}=12 \frac{8200 \cdot 2 \cdot \cos 6^{\circ}}{600}\left(1+0.3 \frac{5}{8}\right)=387 \text {. }
$$

The results of the obtained measurements of the elevation of points $\mathrm{H}$ and subsidence $\Delta H$ (Fig. 4) show that the displacement of the earth surface does not occur uniformly. The maximum value of the subsidence rate occurred at the observed point 3 and was $450 \mathrm{~mm} / \mathrm{month}$ that is $63 \mathrm{~mm}$ more than the theoretical value $v_{\text {theor }}=$ $=387(\mathrm{~mm} / \mathrm{month})$.

Analyzing the data obtained, we found that during the development of the formation suite the character of the earth surface displacement is much more pronounced [18] in comparison with the displacement process indicators during the development of separately located breakage faces.

To establish the parameters of the earth surface displacement, we consider the behavior of the Rp1 networking point depending on the breakage face advancing.

The plot shown in Fig. 5 illustrates changing the vertical displacements of the point in dependence on the position of the face or (assuming the face advancement is uniform) on time.

The analysis of the subsidence of a single point on the earth surface allows distinguishing three stages of its displacement:

- the initial stage characterized by a slight gradual subsidence of the developed unit;

- with further face advancing the point subsidence rate increases, which determines the active stage of the displacement;

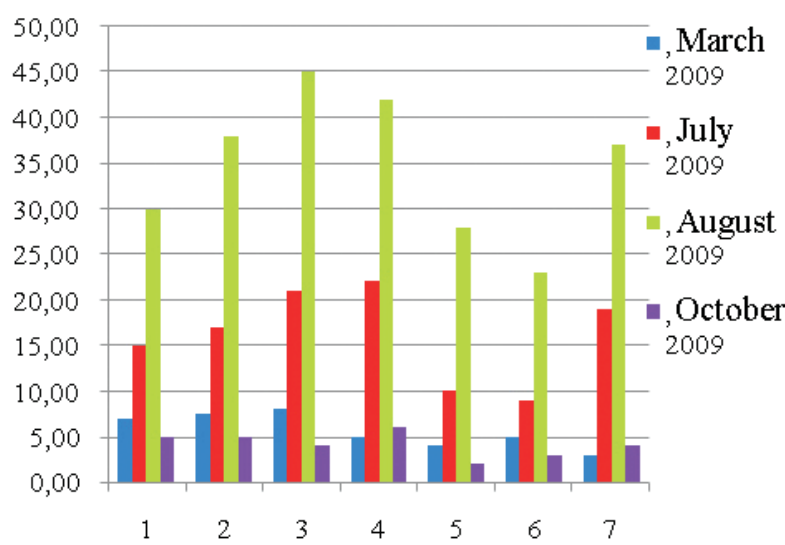

Fig. 4. Diagram of the measured subsidence at points No. $1-7, \mathrm{~cm}$

- the last period is associated with decreasing the subsidence rate of the surface and is considered as the stage of attenuation.

The rate of the vertical displacement of the $V$ point of the GNSS network Rp1 is determined by the ratio of the magnitude of the horizontal displacement to the time within which it occurred, and for each stage is

$$
\begin{gathered}
V_{\text {act.st.beg. }}=0.025 / 2=0.0125 \mathrm{~m} / \mathrm{month}=0.4 ; \\
V_{\text {act.st. }}=0.35 / 10.5=0.033 \mathrm{~m} / \mathrm{month}=1.1 ; \\
V_{\text {act.st.comp. }}=0.035 / 5.5=0.006 \mathrm{~m} / \text { month }=0.2,
\end{gathered}
$$

where $V_{\text {act.st.beg. }}$ is the rate before the active stage beginning, $\mathrm{mm} /$ day; $V_{\text {act.st. }}$ is the active stage rate, $\mathrm{mm} / \mathrm{day}$; $V_{\text {act.st.comp }}$ is the rate after the active stage, $\mathrm{mm} /$ day.

From here for each stage of the surface displacement, the dependence of the points subsidence $H(\mathrm{~m})$ on time $t$ (months) from the beginning of the longwall development can be determined

$$
\begin{gathered}
H_{\text {act.st.beg. }}=0.0125 \cdot t_{\text {act.st.beg. }} ; \\
H_{\text {act.st. }}=H_{\text {act.st.beg. }}+0.033 \cdot t_{\text {act.st. }} ;
\end{gathered}
$$

Duration of observarions, year/month

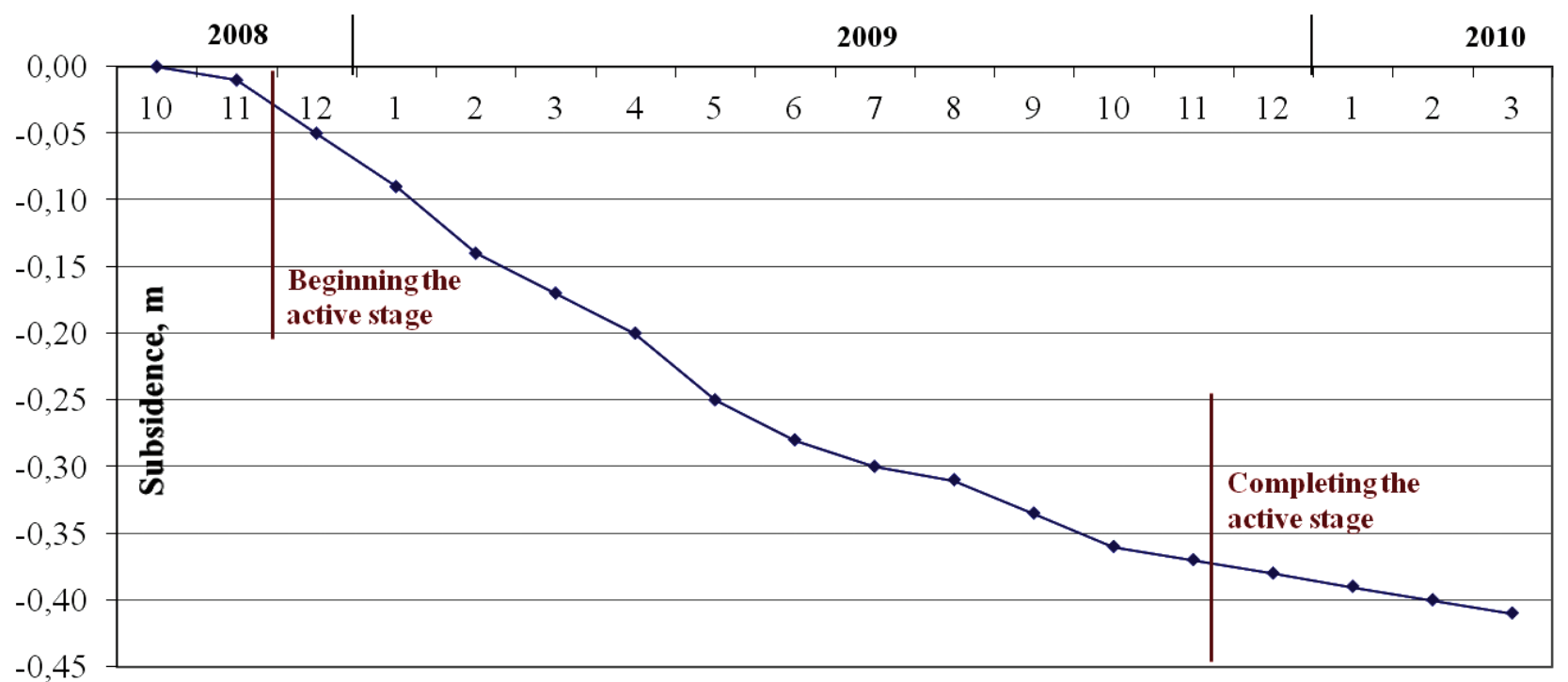

Fig. 5. Plot of vertical displacements of the Rp1 point of the satellite GNSS network depending on time 


$$
H_{\text {act.st.comp } .}=H_{\text {act.st. }}+0.006 \cdot t \text {, }
$$

where $H_{\text {act.st.beg. }}$ is dependence of the points subsidence before the active stage beginning; $H_{\text {actst. }}$ is dependence of the points subsidence at the active stage; $H_{\text {act.st.comp. }}$ is dependence of the points subsidence after the active stage.

The information of the total duration of the process of displacement makes it possible to solve the issues of building undermined areas, and the information of the period of dangerous deformations is used in determining the duration of the repairing structures damaged due to their underworking, and during observations of the objects being undermined.

Conclusions. In general, the process of the earth surface displacement lasted within 16 months. The period of dangerous displacements (from December 2008 to November 2009) was at the end of mining the longwall on the $\mathrm{K}_{12}$ seam and the beginning of mining the longwall on the $\mathrm{K}_{2}-\mathrm{K}_{3}$ and $\mathrm{K}_{7}$ seams.

The use of local small geodetic networks based on GNSS technologies for monitoring the earth surface displacements during underground coal mining makes it possible to determine the values of surface displacements with high accuracy corresponding to the accuracy of class 1 networks [19].

The proposed method of observing the displacement of the earth surface is more economically advantageous and requires significantly less time compared to measurements made using traditional expensive geodetic methods, when high measurement accuracy can be achieved only by completing the whole range of field and office work. The developed method allows obtaining the results of a series of measurements within 8-10 days, while traditional methods take 1.5-2 months.

It is possible to establish a linear dependence of the subsidence of points on the earth surface on time measured from the beginning of the longwall mining. The obtained dependence of the duration of observations on vertical displacements has an exponential form.

The proposed method for monitoring the indicators of the earth surface displacements in mine fields using the GNSS technology makes it possible to determine the parameters of the displacements. Such an approach to the displacement indicators allows avoiding the risks of serious damage to surface structures [20] and significant damage to the natural environment, as well as performing rational excavation of coal reserves.

\section{References.}

1. Panzhin, A.A., Sashurin, A. D., Bolikov, V. E., Ruchkin, V. I., Efremov, E. Yu. and Panzhina, N.A., 2016. Features of geodynamic monitoring at Uzelginskoye field. Problems of Subsoil Use, 4, pp. 81-88.

2. Gavrilenko, Yu.N., Petrushin, A.G. and Kovalev, K. V., 2013. Estimation of displacements and deformations of the earth surface during underground mining of coal deposits using the method of radar interferometry. Transactions of UkrNDMINAN, Ukraine, 12, pp. 366-381.
3. Kaftan, V. I. and Ustinov, A. V., 2015. Improving the accuracy of local geodynamic monitoring by means of global navigation satellite systems. Mining Journal, 10, pp. $32-38$.

4. Gang Chen, Xingwen Cheng, Weitao Chen, Xianjiu Li and Liangbiao Chen, 2014. GPS-based slope monitoring systems and their applications in transition mining from open-pit to underground. International Journal Mining and Mineral Engineering, 5(2), pp. 152-163.

5. Guanwen Cheng, Congxin Chen, Wanchen Zhu and Tianhong Yang, 2018. Numerical modeling of strata movement at footwall induced by underground mining. International Journal of Rock Mechanics and Mining Sciences, August, pp. 142-156.

6. Krasilnikov, P.A. and Seredin, V. V., 2017. The study of patterns and the construction of mathematical models of the distribution of hydrocarbons in the section in the territories of oil refineries. Bulletin of PNRPU. Geology. Oil and Gas and Mining, 2, pp. 191-200.

7. Vervoort, A. and Declercq, P.-Y., 2017. Surface movement above old coal longwalls after mine closure. International Journal of Mining Science and Technology, 27, pp. 481-490.

8. Surveying Department of mine n.a. Kostenko of ArcelorMittal Temirtau JSC; Ch. Surv. Lindeman A. D., 2008. Plans for mining works mine Kostenko: production map. 1:2000. Karaganda, 2008.

9. Tolstunov, S. A. and Montikov, A. V., 2013. The influence of the speed of movement of the stope on the environmental consequences of mining. Notes of the Mining Institute, 203, pp. 112-115.

10. Zubov, V. P. and Viet, K. K., 2015. Practical experience of using systems for the development of powerful steep seams in the conditions of the Quang Nin basin. Mining Information and Analytical Bulletin (scientific and technical journal), pp. 10-14.

11. Avakyan, V.V., 2016. Applied Geodesy. Technology engineering and geodetic works. M.: Infra-Engineering.

12. Guidelines for the creation and reconstruction of urban geodetic networks using satellite systems Glonass. GNSS. M.: Roskartografiya [online]. Available at: $<$ http://docs.cntd.ru/document/1200037141> [Accessed 18 November 2017].

13. Grigoriev, A. E., 2013. Justification of the width of the safety pillars of capital mine workings. Mining information and analytical bulletin (scientific and technical journal). - Moscow, Mining Book, pp. 193-208. Available at: <https://cyberleninka.ru/article/n/obosnovanie-shiriny-predohranitelnyh-tselikov-kapitalnyhgornyh-vyrabotok> [Accessed 9 January 2018].

14. Mironov, A.A., Gussev, V. N. and Kozlov, A.A., 2012. Organization and implementation of deformation monitoring when excavating a suite of coal seams under linear structures in a mine field of Raspadskaya OJSC. Mining information and analytical bulletin (scientific and technical journal) [online], pp. 9-15. Available at: <https://cyberleninka.ru/article/n/organizatsiya-i-vypolnenie-deformatsionnogo-monitoringapri-vyemke-svity-ugolnyh-plastov-pod-lineynymisooruzheniyami-na-shahtnom-pole $>$ [Accessed 23 December 2017]. 
15. The Survey Department of mine n.a. Kostenko of ArcelorMittal Temirtau JSC, 2008. Surface plan of the mine named after Kostenko: production map/Comp. and prep. Ch. Surv. Lindeman A. D. 1:5000. Karaganda. 16. Issabek, T. K. and Ivadilinova, D. T., 2016. Mathematical modeling of the process of the earth surface displacement as a result of undermining coal seams. In: Proc. of the LXIII international scientific-practical conference "Innovations in Science", Novosibirsk, 11(60), pp. 170-176. Available at: <https: //sibac.info/conf/innovation/1xiii/64654> [Accessed 11 January 2018].

17. Rules of protecting buildings and natural objects from the harmful effects of underground mining in the Karaganda basin. Karaganda: KazNIMI, 1997 (remain valid) [pdf]. Available at: <https://my-files.ru/tmxlda/ правила охраны сооружений от вредного влияния подземных горных разработок в Карагандинском угольном бассейне.pdf $>$ [Accessed 24 September 2017].

18. Baryakh, A.A., Devyatkov, S.Yu. and Samodelkin, N.A., 2016. Theoretical substantiation of the conditions for the formation of dips on the earth's surface after emergency flooding of potash mines. Physical and technical problems of the development of mineral resources, 1, pp. 50-62.

19. Gerassimov, A. P., 2012. Satellite geodetic networks. Moscow: Prospectus [online], pp. 15-16. Available at: <http://www.geokniga.org/books/8927> [Accessed 3 October 2017].

20. Ivadilinova, D. T. and Amrenov, K. K., 2014. Geodesic observations of man-made processes. In: IX International Conference of Students and Young Scientists "Science and Education - 2014". Ministry of Education and Science of Kazakhstan, Eurasian National University n.a. L. N. Gumilyov, April 11 [pdf], pp. 4548-4552. Available at: <http://www.enu.kz/downloads/nauka/ sbornik-konferencii-izmenennyi.pdf $>$ [Accessed $13 \mathrm{Au}-$ gust 2017].

\section{Моніторинг зрушень земної поверхні на пунктах малої геодезичної мережі при підземному відпрацюванні вугілля}

\section{Т. К. Ісабек, В. Ф. Дьомін, Д. Т. Іваділінова}

Карагандинський державний технічний університет, м. Караганда, Республіка Казахстан, e-mail: dinulb@mail.ru

Мета. Розробка економічної та високоточної методики спостережень за деформаціями земної поверхні при видобутку корисних копалин підземним способом.

Методика. Застосовані експериментальні графо-аналітичні методи, а також математичне моделювання.

Результати. Представлена методика та результати обробки даних спостережень за зрушенням земної поверхні при видобутку кам'яного вугілля на шахті „Імені Костенко“ Вугільного департаменту АТ „АрселорМіттал Теміртау“, Карагандинський вугільний басейн. Вимірювання зру- шень виконані на пунктах малої геодезичної мережі за допомогою GNSS технологій з точністю, допустимою для супутникової геодезичної мережі 1 класу. Результати підтверджують ефективність GNSS методів при вивченні зрушень земної поверхні в умовах вугільних шахт. Визначені вектори зсувів пунктів GNSS, отримані чисельні значення відносних вертикальних і горизонтальних зсувів точок.

Наукова новизна. Розроблена нова методика проведення геодезичних вимірювань при дослідженні зрушень земної поверхні при її підробці побудовою локальних малих геодинамічних мереж. Уперше спостереження за зрушенням земної поверхні внаслідок іiї підробки на території Карагандинського вугільного басейну проводилися не за профільними лініями, а в результаті детальної зйомки поверхні.

Практична значимість. Запропонована методика проведення геодезичних вимірювань з використанням GNSS технологій для дослідження зрушень земної поверхні дозволила з високим ступенем точності визначити параметри процесу зрушення та може служити основою для організації геодезичного моніторингу на території всіх шахт, що перебувають у Карагандинському вугільному басейні. Основним інструментом зі спостереження за техногенними процесами стала мережа спеціально запроектованих реперів на родовищі. За систематичного моніторингу, коли спочатку реалізуються заходи зі створення геодинамічного полігону, досягається найбільший ступінь прогнозування ризиків експлуатації родовища.

Ключові слова: вугілля, спостереження, рух землі, GNSS, точність вимірювань, детальне обстеження, підземна розробка

\section{Мониторинг сдвижений земной поверхности на пунктах малой геодезической сети при подземной отработке угля}

\section{Т. К. Исабек, В. Ф. Дёмин, Д. Т. Ивадилинова}

Карагандинский государственный технический университет, г. Караганда, Республика Казахстан, e-mail: dinulb@mail.ru

Цель. Разработка экономичной и высокоточной методики наблюдений за деформациями земной поверхности при добыче полезных ископаемых подземным способом.

Методика. Применены экспериментальные графо-аналитические методы, а также математическое моделирование.

Результаты. Представлена методика и результаты обработки данных наблюдений за сдвижением земной поверхности при добыче каменного угля на шахте „Имени Костенко“ Угольного департамента АО „АрселорМиттал Темиртау“, Карагандинский угольный бассейн. Измерения сдвижений выполнены на пунктах малой геодезической сети с помо- 
щью GNSS технологий с точностью, допустимой для спутниковой геодезической сети 1 класса.

Результаты подтверждают эффективность GNSS методов при изучении сдвижений земной поверхности в условиях угольных шахт. Определены векторы смещений пунктов GNSS, получены численные значения относительных вертикальных и горизонтальных смещений точек.

Научная новизна. Разработана новая методика проведения геодезических измерений при исследовании сдвижений земной поверхности при ее подработке построением локальных малых геодинамических сетей. Впервые наблюдения за сдвижением земной поверхности вследствие ее подработки на территории Карагандинского угольного бассейна производились не по профильным линиям, а в результате детальной съемки поверхности.

Практическая значимость. Предложенная методика проведения геодезических измерений с ис- пользованием GNSS технологий для исследования сдвижений земной поверхности позволила с высокой степенью точности определить параметры процесса сдвижений и может служить основой для организации геодезического мониторинга на территории всех шахт, находящихся в Карагандинском угольном бассейне. Основным инструментом по наблюдению за техногенными процессами явилась сеть специально запроектированных реперов на месторождении. При систематическом мониторинге, когда изначально реализуются мероприятия по созданию геодинамического полигона, достигается наибольшая степень прогнозирования рисков эксплуатации месторождения.

Ключевые слова: уголь, наблюдение, движение земли, GNSS, точность измерений, детальное обследование, подземная разработка

Рекомендовано до публікації докт. техн. наук А. Ж. Імашевим. Дата надходження рукопису 28.01.18. 